\title{
Sustainable Development Management: Actors and Institutions in the Post-Industrial Era
}

\author{
Nina Kazitskaya ${ }^{1}$, Vera Prusova $^{1}$ and Sergey Bochkov ${ }^{1}$ \\ ${ }^{1}$ Moscow Automobile and Road Construction State Technical University (MADI), 125319, 64 \\ Leningradsky av., Moscow, Russia
}

\begin{abstract}
Sustainable Development is a hypothetical development of a society in which human conditions improve and environmental impact is constrained by the regenerative abilities of the biosphere, so that the natural basis of human life is not destroyed. Sustainable development assumes that meeting the needs of present and future generations is maintained in a safe state, and that environmental conservation is an integral part of the development process. The era of post-industrialization is radically changing the nature of human exposure to the environment. Before raising the question about the current state of natural resource complexes, it should be recognized that humanity still faces the problem of geoecology at the national level, as part of the industrial policy of each country separately. In the post-industrial world, in which the goods created in one country are consumed all over the world, geoecological problems go global, where any component of the environment - natural, technological, social - are combined in a single chain of production and consumption. All of the above requires the formation of an effective system for managing sustainable development in the transition from an industrial to a post-industrial economy, with its specific subjects, goals and subsystems.
\end{abstract}

\section{Introduction}

In the countries where the post-industrial stage of development has emerged (the advanced countries of the West and Southeast Asia), the consumption of raw materials has been rapidly declining in the last 20-30 years [1]. The formation of a knowledge-based economy contributes to the solution of a number of environmental problems associated with the growth of basic industries - mining, energy, and metallurgy. However, at the global level, this problem is not being solved, since environmentally harmful industries "migrate" to developing countries of early industrialization.

In such countries, the development of industry and the growth of environmental damage are caused by the fight against poverty and unemployment in the industry; therefore, environmental disasters are not rare there. EU countries allocate from $3 \%$ to $6 \%$ of GDP for the development of environmental projects, in the USA - $2.5 \%$ of GDP, with an annual increase [2]. As a result, as a result of environmental actions in these post-industrial countries, the pressure on the environment has decreased, and the production of consumer goods has increased. The International Monetary Fund estimates the reduction of the consumption of natural resources for the production of finished goods at $1.23 \%$ per year for the twenty most 
developed countries in the world [3]. For example, the recycling of industrial waste in West Germany is approaching 100\%: spent rubber and industrial oils - 90\%, car parts - 98\% [4]. At the same time, the environmental direction of post-industrial development is achieved due to geographical changes in the structure of the economies of developed countries, consisting in the fact that energy-intensive and material-intensive industries are replaced by high-tech and knowledge-intensive, as well as moving to less developed ones.

Obviously, the objectivity of research on sustainable development in the post-industrial world requires highlighting the complex intertwined economic ties of the most developed and developing countries, largely due to the cooperation of large, medium and small firms around the world. Consumer demand of the population of developed countries have not decreased; on the contrary, it is constantly increasing. Today, a resident of a developed country consumes as many natural resources embodied in various benefits as there are 20 people from developing ones (mainly energy carriers and building materials), and the energy consumption of one American is equivalent to 14 Chinese or 531 Ethiopians [5]. In general, the developed countries of the "golden billion" consume $50 \%$ of the world's electricity and $80 \%$ of natural resources [6].

However, in 2000s there has been a differentiation between developed and developing countries in terms of consumption of natural resources, in particular, energy sources, which for developing countries has grown by almost $70 \%$, and in developed countries only by $5 \%$ [7]. Over the same period, GDP in developing countries grew by $60-70 \%$, and in developed countries - by $25-30 \%$ [8]. Further, over the past 30 years, there has been a decrease in the share of consumption of natural resources in the GDP of advanced countries: the United States -1.6 times, Canada -1.9 times, Japan -2.2 times, Germany -2 times, Italy -2.6 times [9]. Post-socialist and developing countries continue following the extensive way of catching-up development, that is, the volumes of resource consumption for them change in parallel (or even faster) with the growth of the economy (in Russia, resource consumption decreased by $10 \%)$ [10].

\section{Materials and Methods}

The sustainable development methodology consists of the following conceptual approaches:

1. The law on the irreversibility of evolution (Dollo's law [11]) - is a universal law that states that an organism (population) cannot turn into a state that has already been embodied in one of its ancestors, even outside its habitat (not a single species and not a single group of species appeared twice). V. Vernadsky applied this law to the development of the biosphere as a whole [12]. According to him, the irreversibility of a progressive process is a demonstration of differentiation between a living being in the geological history of the planet and non-living bodies. In fact, all changes occurring on Earth under the influence of living organisms are irrevocable, namely, a change in the composition of the atmosphere, the formation of the soil layer, etc.

2. The law on discrete evolution - the evolution of living organisms and the biosphere as a whole develops non-linearly and abruptly. Fluctuations in the formation of species occur due to biological reasons (hybridization, horizontal gene transfer) and the periodic activation of tectonic forces. There are conservative species that have been changed only during geological eras, including some bacteria that have not been modified since the earliest species were the most conservative. Just like genes in biology, in the social world there is a transfer of technologies, institutions and cultural elements from one community to another, which leads to leaps in the development of several states (in South Korea, Singapore, Japan, etc.). d.).

3. Theories of discontinuous equilibrium and quantum evolution - patterns of evolution in living nature, developed by N. Eldredge and S.J. Gould, according to which the 
evolutionary mechanism acts by uneven bursts, interspersed by periods of constancy. This theory is opposed to the theory of phyletic gradualism in which most of the evolution proceeds progressively [13].

4. Saltationism - the approach of evolutionism associated with leaps in evolution. The genesis of new species occurs very quickly over several generations. In contrast to the synthetic theory of evolution, saltationism does not explain in detail the absence of a continuous series of transitional forms, as well as the sharp decline in the competitiveness and vital activity of transitional forms.

5. Sustainable use of natural resources, according to which there is such an optimal level of pressure on non-renewable resources that does not in the foreseeable future lead to their depletion, thereby retaining the ability to satisfy the needs of present and future generations (D.H. Meadows). Such optimal use of natural resources must comply with three conditions [14-15]:

- compliance with the growth rate of consumption of renewable resources to the rate of their regeneration;

- compliance of the growth rate of consumption of non-renewable resources with the production rate of their renewable substitutes;

- correspondence of the intensity of nature pollution to the capacity of assimilation by their ecosystems.

6. Sustainable use of land and forests established by the Helsinki Declaration of the Ministerial Conference on Forest Protection (1995). It involves the management of forest areas in such a way that the conservation of biological diversity, the ability of the plant and animal world to renew and preserve vitality, without prejudice to other ecosystems.

\section{Results and Discussion}

The most important element of sustainable development management - its goal-setting - is clearly reflected in the UN Agenda for Sustainable Development until 2030. Each of the 17 goals has a number of indicators that should be achieved within the next fifteen years due to the joint efforts of all segments of the modern society of developed and developing countries in pursuance of the Millennium Declaration adopted by the UN General Assembly in 2000. Totality of this goals includes: elimination extreme forms of poverty and reducing its overall level; elimination of regions with starving populations; improving health and achieving general well-being; ensuring access to quality education and gender equality; providing clean water, sanitary living conditions and inexpensive environmentally friendly energy; decent work and economic growth; industrialization and infrastructure development, including innovation; urbanization; reduction of economic inequality and the transition to environmentally responsible production and consumption; conservation of ecosystems of the sea and land.

The fifteen-year period of the 2030 Agenda for Sustainable Development has the following several differences from the period of the Millennium Declaration: the feasibility of eradicating extreme poverty and also poverty in all its manifestations, the much more significant human impact on the Earth, and rapid technological changes, growing inequality, as well as the increasing diffusion of innovations and the increasing complexity of managing economic, environmental and social systems.

The main components of sustainable development, according to UN experts, include:

- progressive social development (adequate nutrition for all, quality education for all, reduction in mortality and morbidity, gender equality, adequate social protection);

- inclusive economic development (eradicating low incomes that cause poverty and hunger, reducing inequality, providing jobs, employment, etc.) 
- environmental sustainability (protecting biodiversity, maintaining climate, universal access to clean water);

- personal security (freedom from violence, conflict and ill-treatment, resistance to natural disasters, conflict-free access to natural resources).

The essence of sustainable development is revealed in many documents (World Strategy for Nature Conservation, 1979, 1980; report "Our Common Future" of the International Commission on Environment and Development, led by G.H. Brundtland, 1984-1987). However, the concept of sustainable development itself was spread at the United Nations Conference on Environment and Development in Rio de Janeiro (1992), which was presented there as a prerequisite for the progress of humanity over the long term, accompanied by increased capital and improved environmental conditions.

The concept of sustainable development implies the development of a country for the self-organization of its economy and the environment, which impedes the transition of society into a state of uncontrolled waste of non-renewable resources. For mankind in a general sense, this concept implies an efficient and goal-directed movement of resources from resource-rich regions to resource-poor through a wide exchange of knowledge and information about the environment. "Sustainable development" as an environmental and economic phenomenon contains a contradiction, which consists in the fact that, on the one hand, the limitation of the consumption of natural resources occurs against the background of a constant increase in well-being (mainly material), and on the other hand, contradict to it [16-18]. From the point of view of evolution, the combination of the terms "sustainability" and "development" is incompatible (life is development, and support in the aspect of evolution is a deterrent to development).

Further, the concept of sustainable development is in conflict with the basic laws of development (the law of irregular evolution, the law of irreversibility of evolution, and so on). During evolution, the stability of ecosystems increases, and their sustainability decreases. In modern societies, the peak of economic growth often exceeds long-term goals, which causes an overspending of resources in industry in developed countries and all of humanity in particular. Therefore, a certain drawback of the Sustainable Development Concept is its understanding from a purely economic point of view, while for humanity (and recent events confirm this) economic growth is not the only element of sustainable wellbeing. A series of global crises that began in 2008 and continues to this day, as well as interstate conflicts, clearly demonstrate the declarative nature of today's understanding of the concept of sustainable development.

The problem of sustainable development in the interpretation of the UN does not consist in what true scientific and conceptual validity dominates. Summarizing the recommendations of representatives of all countries of the world, the concept of sustainable development was not supplemented with appropriate methods of natural science. Despite the wide scope of interpretations of the concept of sustainable development (although the criteria of science, for the most part, and unfortunately, it not observed), a generally accepted understanding of this phenomenon is not always demonstrated.

Along with the goals, sustainable development management in the post-industrial world includes a number of subjects of this process:

A) United Nations Commission on Sustainable Development, UNCSD) - an organization formed in 1992 by the United Nations as a result of the World Summit, bringing together 53 states to help solve the most pressing problems: providing the Earth's population with fresh water; development of clean energy and transport; protection of forests, oceans.

B) Committee on Environment and Sustainable Development) - created in 1989 by the Inter-Parliamentary Union based on 131 states, designed to contribute to the process of sustainable development at the national and global levels in the course of fulfilling the 
recommendations of the UN Conference on Environment and Development, collecting information on the implementation of the UN recommendations on environmental protection.

C) United Nations Conference on Environment and Development, UNCED) - an international meeting under the auspices of the United Nations to ensure the interaction of countries on topical environmental issues (protection of the atmosphere, land and water resources, development of biotechnology).

D) International Institute for Environment and Development, IIED - a research and educational center established in 1971 with the goal of modeling sustainable development, organizing consultations and information transfer, training in the fields of sustainable agriculture, environmental management, environmental economics, countering climate change.

Thus, adequate governance for sustainable development is one that promotes inclusive and equitable social development, environmental sustainability, security and non-conflict policies.

In the sustainable development management system, the nature of the relationships that underlie the interactions of the subjects, which determines the conditions and principles of the construction, functioning and transformation of this system, is manifested in its following subsystems:

- structural and functional subsystem - a complex of bodies, divisions and performers that implement their functions and perform assigned tasks, as well as a set of methods by which management is carried out;

- informational and behavioral subsystem - a set of ideological guidelines and values for sustainable development management, a set of interests and behavioral attitudes of sustainable development management entities, the movement of information between them and building communications.

\section{Conclusion}

Summarizing the above, the institutional support of the system for managing the transition to sustainable development should link together all its subjects and reflect the nature of the subsystems. Sustainable development management institutions thus include public-andprivate and interstate partnerships, international environmental cooperation, standards for the provision of financial and other assistance for sustainable development, corporate environmental and social responsibility.

\section{References}

1. S. Zhironkin, S. Demchenko, G. Kayachev, M. Ryzhkova, O. Zhironkina, E3S Web Conf., 41, 04011 (2018)

2. S. Zhironkin, O. Aleshina, V. Gorev, Y. Gunyakov, O. Zhironkina, E3S Web of Conferences, 105, 04001 (2019)

3. V.V. Guzyr', Economics and Innovation Management, 4, 4-19 (2019) DOI: 10.26730/2587-5574-2019-4-4-19

4. A.G. Koryakov, M.V. Kulikov, Economics and Innovation Management, 4, 16-26 (2018) DOI: $10.26730 / 2587-5574-2018-4-16-26$

5. S. Zhironkin, D. Khloptsov, N. Skrylnikova, I. Petinenko, O. Zhironkina E3S Web Conf., 41, 04010 (2018)

6. Gasanov E.A. Economics and Innovation Management, 2, 39-49 (2019) DOI: 10.26730/2587-5574-2019-2-39-49 
7. Cehlar M. Economics and Innovation Management, 3, 24-31 (2019) DOI: 10.26730/25875574-2019-3-24-31

8. E.V. Slesarenko, Economics and Innovation Management, 4, 4-15 (2018) DOI: 10.26730/2587-5574-2018-4-4-15

9. S. Zhironkin, S. Demchenko, G. Kayachev, E. Taran, O. Zhironkina, E3S Web of Conferences, 105, 03008 (2019)

10. T. Skryl, E. Shavina, E. Dotsenko, $\quad$ E3S Web Conf., 105, 04049 (2019)

11. J. Farris, Systematic Zoology, 26(1), 77-88 (1977)

12. P. Josephson, N. Dronin, R. Mnatsakanyan, A. Cherp, D. Efremenko, A. Larin, An Environmental History of Russia (Cambridge University Press, New York, 2013)

13. S.J. Gould, N. Eldredge, Nature, 366:6452, 223-227 (1993)

14. T. Skard, Gro Harlem Brundtland. Women of Power: Half a Century of Female Presidents and Prime Ministers Worldwide (Policy Press, Bristol, 2014)

15. V. Frolova, O. Dolina, T. Shpilkina, E3S Web of Conf., 105, 01054 (2019)

16. T. Snegireva, G. Kayachev, A. Falaleev, S. Kurgansky, E3S Web Conf., 134, 03014 (2019)

17. N. Zaruba, T. Fraltsova, T. Snegireva, E3S Web Conf., 21, 04028 (2017)

18. N. Kudrevatykh, T. Snegireva, A. Tselischeva, E3S Web Conf., 15, 04006 (2017) 